\title{
THE PEOPLE SIDE OF SUCCESSFUL BUSINESS TRANSFORMATIONS
}

\author{
Metin Begecarslan ${ }^{1}$ \\ ${ }^{1}$ Mendel University in Brno, Czech Republic
}

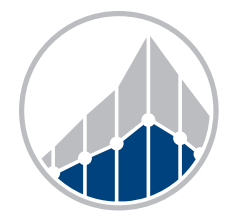

EUROPEAN JOURNAL OF BUSINESS SCIENCE AND TECHNOLOGY

Volume 7 Issue 1

ISSN 2694-7161

www.ejobsat.com

\begin{abstract}
Business transformations are critical to making a giant leap to create an outstanding customer experience and dominate the market. This study explores how companies with different Continuous Improvement Maturities manage the people side of a business transformation, focusing on establishing a Continuous Improvement culture. A semi-structured interview with 28 different companies and 30 interview partners from 21 different industries will explore the People Excellence approach's differences in People Engagement, People Enablement, and People Empowerment. The study also investigates the different views on Continuous Improvement Systems and their impact on the organization. The focus on people, culture, and Leadership to achieve significant and sustainable business results from companies with a strong Continuous Improvement System will be evident, compared to companies with no structured Continuous Improvement System or a fragile Continuous Improvement System.
\end{abstract}

\section{KEY WORDS}

leadership, business transformation, engagement, empowerment, enablement

\section{JEL CODES}

L160, M100

\section{INTRODUCTION}

A quote around 500 B.C. from the ancient Greek philosopher Heraclitus "Change is the only constant in life" (Purkey and Siegel, 2003), is still valid in today's business world. We face different fundamental changes that involve and challenge everyone in the organization- transformations. There are some prevalent types of transformations around in the business world like Lean Transformation, Agile Transformation, and lately Digital Transformation. Generally, transformations have five categories-Business process transformation, In- 
formation/data/digital transformation, Organizational transformation, Management transformation, and Cultural transformation (Müller, 2018).

Independently of which transformation type, the success rates of these transformations are surprisingly low. While de la Boutetière rates Digital Transformation success by $20-30 \%$ (de la Boutetière et al., 2018), rates Tasler, based on surveys from Mc Kinsey conducted in 2009, generally business transformation success by 30-38\% (Tasler, 2017). Another survey from Industry Week and the MPI Census of Manufacturers in 2007 displays that $72.5 \%$ of the companies still have gaps to achieve significant Lean Transformations results (MPI Census, 2007).

Given that organizational outcomes are the collective result of individual changes (Hiatt and Creasey, 2012), this research focuses on the people side of the transformations and how successful companies are approaching People Excellence compared to others. The study's focus is Business Transformation with a Continuous Improvement System and involves multiple industries to avoid industry bias. To have a broad input base and to recognize patterns in multiple Continuous Improvement dimensions, the participating companies for the study targeting criteria's like business revenue from $\$ 0-250 \mathrm{M}$ up to $>\$ 50 \mathrm{Bn}$, employee size from $0-1,000$ up to $>100,000$ employees, diverse industries, diverse Continuous Improvement Maturities. This broad input base makes this study relevant for any industry and any company size, who wants to kick off a Continuous Improvement journey or learn the differences from their people approach compared with companies with a strong Continuous Improvement System.

This study aims to identify how companies with different Continuous Improvement (CI) Maturities approach People Excellence for significant business results. To display and understand the different People Excellence approaches of companies, they are separated into three different Continuous Improvement Maturities - No Systematic CI System (NO), Strong CI System (STRONG), and Fragile CI System (FRAGILE). The research focuses on these companies' People Enablement, People Engagement, and People Empowerment activities.

The paper's structure gives in Section 2 a theoretical background and reviews the literature concerning Continuous Improvement with its maturity and People Excellence. Section 3 displays the methodology and the data of this research. Section 4 displays the research results, and section 5 explores the possible further analysis of future research opportunities.

\section{THEORETICAL BACKGROUND AND LITERATURE REVIEW}

Since Toyota became famous for its Toyota Production System, which was called "Toyota's Secret Weapon in the Global Car Wars" (Womack et al., 1990), numerous companies have tried to copy and paste what Toyota did. When a company starts its Lean journey, in many cases, it also starts to assess its implementation progress and maturity to understand where they are in the journey. There are different models to understand Lean Management implementation maturity, like the Four Levels of Lean Maturity (Panneman, 2017), where four main Lean implementation stages are defined. The most common way in companies is an assessment like Lean Assessments for Job Shops and Small Manufacturers (Kremer and Tapping, 2007). Here, specific methods and principles are evaluated based on the method's or principle's fulfillment implementation. Methods are always easier to evaluate, but it does not reflect the whole picture in a Lean journey. The statement "Do not Just Do lean; Be Lean" (Byrne and Womack, 2013) already explains that the Lean journey is more than only the tools, and Mann describes the importance of creating a Lean culture to 


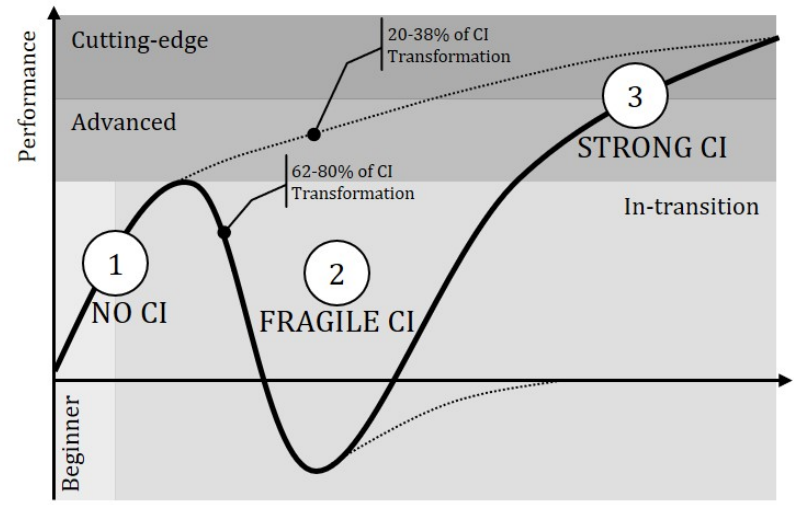

Fig. 1: CI Maturity Model: CI Trust Curve

sustain Lean transformations (Mann, 2015). To measure the cultural changes in a Lean journey, researchers already added cultural aspects in the Lean assessment matrices (Donovan, 2015; Nesensohn et al., 2014; Nightingale and Mize, 2002). A broader and holistic way for companies already on their Lean journey provides the Shingo Model, named after Shigeo Shingo, who worked with Taiichi Ohno in the early stages of the Toyota Production System. In this Maturity Assessment, the evaluation targets multiple dimensions like Guiding Principles, Cultural Enablers, Continuous Improvement, Enterprise Alignment, and Results (Plenert, 2018). To finalize the Shingo assessment, the assessment team also provides additional written, detailed feedback to understand the score's details (Edgeman, 2019).

To have a less complex, high-level, and easyto-understand maturity model and its impact on performance during a Lean implementation, the "S-Curve Effect of Lean Implementation" is beneficial (Netland and Ferdows, 2016). The SCurve displays the Lean Maturity in sequential stages like Beginner, In-Transition, Advanced, Cutting-Edge on the $x$-axis and the Plant Operational Performance on the $y$-axis, where the operational performance increases in an S-type curve while progressing the sequential implementation stages. For this research, the SCurve Model was taken as a maturity model and was re-designed based on the learnings from the Lean transformation success rates of several surveys and researches mentioned in the introduction (de la Boutetière et al., 2018; MPI Census, 2007; Tasler, 2017). In the mentioned studies, the success rate was about 20 $38 \%$, which would mean $62-80 \%$ of the transformations would stick in the "in-transition" stage of the S-Curve (Netland and Ferdows, 2016). To consider the companies stuck in this "in-transition" stage, the researcher has developed the "Continuous Improvement (CI) Trust Curve" with the CI Maturity categoriesNo Systematic CI System, Fragile CI System, Strong CI System (Fig. 1). This curve is a "Trust Curve" because people believing and trusting in Continuous Improvement will always find a way to establish a sustainable Continuous Improvement System and culture, helping the business overperform. It also highlights the phenomenon that the second trial for kicking off a Continuous Improvement journey is much more challenging than the first trial because people lost trust and faith in the success and have developed a negative view of Lean (Mortson, 2020). Performance always follows trust in the CI System and Leadership in both directions (Tab. 1).

In the meantime, there are very successful companies like Danaher or Honeywell (Begecarslan, 2017) who found their way in the Lean journey and managed to establish an overperforming Continuous Improvement culture. Those companies have understood what Taiichi Ohno, Architect of Toyota Production System (TPS), meant with "... those who decide to implement the Toyota Production System must 
Tab. 1: CI Trust Curve Stages and Trust-Performance Relation

\begin{tabular}{llc}
\hline Lean Maturity & Performance Stage & Trust-Performance Relation \\
\hline $1-$ No Systematic CI System & Beginner, In-Transition & Trust $\geq$ Performance \\
$2-$ Fragile CI System & In-transition failed & Trust $<$ Performance \\
& In-transition CI System reviewed & \\
$3-$ Strong CI System & Advanced, Cutting-edge & Trust = Performance \\
\hline
\end{tabular}

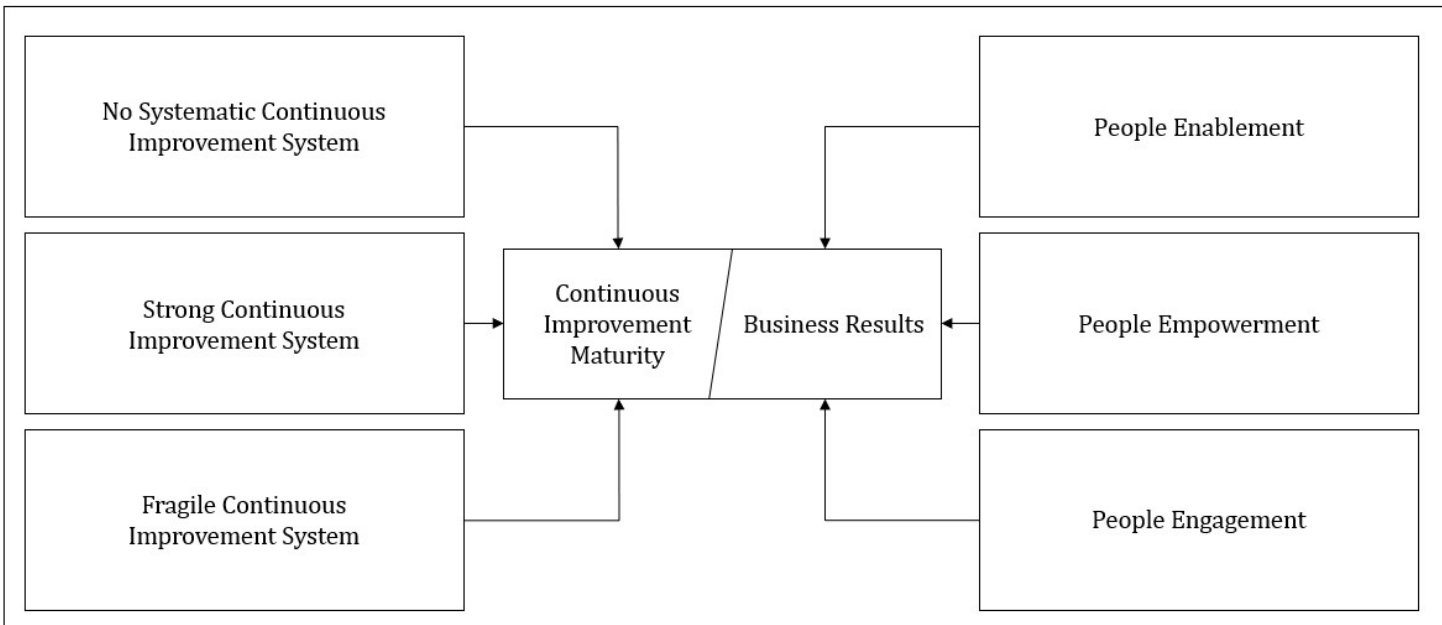

Fig. 2: Expected Relations based on the findings of the survey of literature

be fully committed. If you try to adopt only the 'good parts' you'll fail." (Shinohara, 1988). Fully committed not only means having a holistic system in place and having the discipline to follow the standards. It also means to invest in people because the core of Toyota's philosophy is the belief that people are the greatest asset (Liker, 2020). Their leaders choose to say that they "build people, not just cars" (Liker and Meier, 2006). To achieve People Excellence and with that business results, three dimensions are essential-People Engagement, People Enablement, People Empowerment (Permana et al., 2015). While there are different definitions of People Engagement, most of them are about the employees' strong connection with their work, organization, or colleagues (McPhie, 2008). People Engagement goes beyond simple job satisfaction; it is more about taking pride in the work the people deliver and how and where they do it (McPhie, 2008). In its essence, People Enablement is a holistic approach towards the individual development of the people (Maier, 2019) and helps them think in a process context and deal with changes successfully (Shishkov, 2016). According to Blanchard, People Empowerment provides authority and responsibility to the people to make business decisions and a combination of releasing people's engagement and people's knowledge and experience (Blanchard et al., 1999).

Based on the existing literature and the newly defined CI Maturities, the following basic questionnaire setup was developed (Fig. 2):

1. CI Maturity: questions to verify initial clustering of CI Maturity and display different definitions of a CI System

2. People Engagement: understand how leaders create excitement and engagement for CI

3. People Enablement: understand how companies develop their people in CI

4. People Empowerment: understand how leaders empower people to drive CI 


\section{METHODOLOGY AND DATA}

\subsection{Philosophy of Research}

The researcher has chosen the Interpretivist Qualitative research philosophy due to the nature of the topic and designed open-ended interview questions for the best interpretation of the answers. These questions enable observations during the semi-structured conversation and create room for debate and new surprising facts or puzzles, connecting people's side of business transformations with strong business results (Saunders et al., 2019).

\subsection{Population and Sample Size}

This study has targeted 30 top leaders from 21 different industries worldwide to reach a diverse structure of companies. The population is considering the following factors:

1. The industry where the company is operating

2. The size of the company (revenue and number of employees)

3. The hierarchical level of the interview partner (6 General Managers/Directors, 15 Functional Senior Experts/Leaders, 9 $\mathrm{VP} / \mathrm{SVP} / \mathrm{CEO} /$ Lean Authors)

\section{The Continuous Improvement Maturity}

The sample size was selected based on research-type-related recommendations, where the range of the sample size recommendations varies from 1-50 interviews (Mertens, 2005). To have the best possible selection of interview partners, the study started with talking to 50 different leaders to participate in the study, of which 31 finally participated in the interview process. The results later considered only 30 interviews to have an equal number of interviews for the three selected Continuous Improvement Maturities (Tab. 2).

\subsection{Data Collection}

Interviews are an essential data collection strategy (DePoy and Gitlin, 2011), so also used as one-to-one interviews in this phenomenological research. These interviews were conducted faceto-face, per video calls or phone calls, given the participants' multi-geographical locations. Interview participants agreed individually for a one-hour time slot. To entirely focus on the interview interaction and facilitate an open discussion, interviewees permitted to record the interviews (Magnusson and Marecek, 2015). An interview guide with five open-ended questions provided a discussion guideline and a comparable qualitative research database.

\subsection{Data Analysis}

The conducted 30 interviews were transcribed after the complete interview process to have the best view of the entire data set. With the stepby-step Model of summarizing content analysis (Mayring, 2010), this data was classified into clusters of information and finally evolved into a category system for answers to each of the five questions. Due to the nature of the semi-structured interview, the candidates' gave multiple different answer opportunities to the different questions, which leads to different total responses per question. The content summarizing process happened with continuously reviewing the original transcription and the interview's audio record to ensure that the answer's essence is appropriately captured (Mayring, 2010). The relationship of the categorical data is analyzed using Minitab and Excel with the Pearson's chi-squared test and Fischer's exact test, both with a significance level of $\alpha=0.05$. In order to have the best possible interpretation, the $p$-values are also calculated in meaningful summarized groups of responses to have the necessary value $>5$ per cell. However, due to the low numbers even after summarizing in groups, the primary method used is Fischer's exact test. Another interpretation of the data provides the relative frequency comparison from the displayed contingency tables.

Part of the interview process was explaining and the promise of confidentiality, the participants' and the companies' anonymity. All 
Tab. 2: Number of interviews per company size and CI Maturity

\begin{tabular}{|c|c|c|c|c|c|}
\hline Revenue & Employees & $\begin{array}{c}\text { No Systematic CI } \\
\text { System }\end{array}$ & $\begin{array}{c}\text { Strong CI } \\
\text { System }\end{array}$ & $\begin{array}{c}\text { Fragile CI } \\
\text { System }\end{array}$ & $\begin{array}{l}\text { \# of Total } \\
\text { Interviews }\end{array}$ \\
\hline 0-250 Mio & $0-1,000$ & 3 & 1 & & 4 \\
\hline 0-250 Mio & $1,000-10,000$ & 1 & & & 1 \\
\hline 250 Mio-3 Bn & $1,000-10,000$ & & & 2 & 2 \\
\hline $250 \mathrm{Mio}-3 \mathrm{Bn}$ & $10,000-50,000$ & 2 & 1 & & 3 \\
\hline $3-10 \mathrm{Bn}$ & $1,000-10,000$ & 1 & & & 1 \\
\hline 3-10 Bn & $10,000-50,000$ & 1 & 1 & 3 & 5 \\
\hline $10-50 \mathrm{Bn}$ & $10,000-50,000$ & & 1 & 1 & 2 \\
\hline $10-50 \mathrm{Bn}$ & $50,000-100,000$ & 1 & 1 & 1 & 3 \\
\hline $10-50 \mathrm{Bn}$ & $>100,000$ & 1 & 2 & 1 & 4 \\
\hline$>50 \mathrm{Bn}$ & $>100,000$ & & 2 & 2 & 4 \\
\hline $\mathrm{n} / \mathrm{a}$ & $\mathrm{n} / \mathrm{a}$ & & 1 & & 1 \\
\hline Total & & 10 & 10 & 10 & 30 \\
\hline
\end{tabular}

Tab. 3: Years of CI implementation in Companies

\begin{tabular}{|c|c|c|c|c|c|c|c|c|}
\hline CI Maturity & 1-5 Years & 6-10 Years & 11-15 Years & 16-20 Years & 21-40 Years & $>40$ Years & No CI System & $\mathrm{n} / \mathrm{a}$ \\
\hline $1-\mathrm{No}$ & 2 & 3 & & & & & 5 & \\
\hline 2 - Strong & & & 4 & 1 & 2 & 2 & & 1 \\
\hline 3 - Fragile & 3 & 4 & 2 & 1 & & & & \\
\hline Total & 5 & 7 & 6 & 2 & 2 & 2 & 5 & 1 \\
\hline
\end{tabular}

the mentioned specific Production Systems or Business Systems names changed and generalized to "Continuous Improvement System" to ensure the company's anonymity. As also critical facts, opinions, and statements towards an organization's Leadership or culture are part of the expected responses, confidentiality and anonymity were necessary to create an open and secure environment, where participants could expect the respectful and discrete handling of all data (King and Horrocks, 2010).

\section{RESULTS}

\subsection{Continuous Improvement (CI) Maturity}

After the pre-categorizing of the companies in the three defined CI Maturities, the companies answered three questions to display how they define their CI System and why it is successful or not. Five $(16.6 \%)$ responded that they have no CI System in place, and one responded with a "not applicable" as this person is not active in the industry anymore but has worked in one of the most known Lean companies for a long time. The calculated $p$-value $<0.001$ with Fischer's exact test rejects the null hypothesis. That means there is a significant relationship between the CI Maturity and the years a company has a CI System. All "2-Strong" (Strong CI System) respondents have at least 11 years of CI implementation in their companies (Tab. 3).

The question about the description of their present CI System/approach was answered very broadly (Tab. 4). From "not applicable" for some of the cluster "1-NO Systematic CI System" to more visible Tool and System setups, up to culture and value beliefs. The most recognizable relative differences in the answers between the "2-STRONG CI System" companies and the two other type companies 
Tab. 4: Description of the companies CI Systems

\begin{tabular}{|c|c|c|c|c|c|c|}
\hline & 1-NO & 2-STRONG & 3-FRAGILE & Total & $\begin{array}{c}\text { Difference } \\
\text { 2-STRONG } \\
\text { to } 1-\mathrm{NO}\end{array}$ & $\begin{array}{c}\text { Difference } \\
\text { 2-STRONG } \\
\text { to } 3 \text {-FRAGILE }\end{array}$ \\
\hline Tools & $4(30.8 \%)$ & $2 \quad(6.9 \%)$ & $7(33.3 \%)$ & $13(20.6 \%)$ & -2 & -5 \\
\hline Culture & & $7(24.1 \%)$ & $2 \quad(9.5 \%)$ & $9(14.3 \%)$ & +7 & +5 \\
\hline $\begin{array}{l}\text { Continuous } \\
\text { Improvement }\end{array}$ & $1 \quad(7.7 \%)$ & $6(20.7 \%)$ & $1 \quad(4.8 \%)$ & $8(12.7 \%)$ & +5 & +5 \\
\hline System & & $2 \quad(6.9 \%)$ & $6(28.6 \%)$ & $8(12.7 \%)$ & +2 & -4 \\
\hline $\begin{array}{l}\text { Improvement } \\
\text { Proposal System }\end{array}$ & $3(23.1 \%)$ & & $3(14.3 \%)$ & $6 \quad(9.5 \%)$ & -3 & -3 \\
\hline Strategy & $1 \quad(7.7 \%)$ & $3(10.3 \%)$ & $1 \quad(4.8 \%)$ & $5 \quad(7.9 \%)$ & +2 & +2 \\
\hline $\mathrm{n} / \mathrm{a}$ & $3(23.1 \%)$ & & & $3(4.8 \%)$ & -3 & 0 \\
\hline People Development & $1 \quad(7.7 \%)$ & $2 \quad(6.9 \%)$ & & $3(4.8 \%)$ & +1 & +2 \\
\hline Customers & & $2 \quad(6.9 \%)$ & $1 \quad(4.8 \%)$ & $3(4.8 \%)$ & +2 & +1 \\
\hline Standards & & $2(6.9 \%)$ & & $2 \quad(3.2 \%)$ & +2 & +2 \\
\hline Flow & & $1 \quad(3.4 \%)$ & & $1 \quad(1.6 \%)$ & +1 & +1 \\
\hline Transparency & & $1 \quad(3.4 \%)$ & & $1 \quad(1.6 \%)$ & +1 & +1 \\
\hline Values & & $1 \quad(3.4 \%)$ & & $1 \quad(1.6 \%)$ & +1 & +1 \\
\hline Total & $13(100 \%)$ & $29(100 \%)$ & $21(100 \%)$ & $63(100 \%)$ & & \\
\hline
\end{tabular}

Tab. 5: CI System success classification of participating companies

\begin{tabular}{|c|c|c|c|c|}
\hline & 1-NO & 2-STRONG & 3-FRAGILE & Total \\
\hline Not successful & $8 \quad(80 \%)$ & & $2(20 \%)$ & $10(33.3 \%)$ \\
\hline Partially successful & $(20 \%)$ & & $(50 \%)$ & $7(23.3 \%)$ \\
\hline Successful & & $10(100 \%)$ & $3 \quad(30 \%)$ & $13(43.3 \%)$ \\
\hline Total & $10(100 \%)$ & $10(100 \%)$ & $10(100 \%)$ & $30(100 \%)$ \\
\hline
\end{tabular}

are "Culture" ("1-NO Systematic CI System" +7, "3-FRAGILE CI System" +5), "Continuous Improvement" ("1-NO Systematic CI System" +5, "3-FRAGILE CI System" +5), and "Tools" ("1-NO Systematic CI System" -2, "3FRAGILE CI System" -5). The top answers for "3-FRAGILE CI System" are set of "Tools" (33.3\% of their responses), "System" $(28.6 \%)$, and "Improvement proposal System" (14.3\%), where employees can bring their input in a (mostly) IT System and get rewarded for their ideas. The top answers for "1-NO Systematic CI System" are similar. Set of "Tools" (30.8\%) and "Improvement proposal System" (23.1\%). Simultaneously, these two answers do not play a significant role in the "2-STRONG CI System" companies. While "Tools" represents only $6.9 \%$ of the responses, "Improvement proposal System" is not mentioned. This result does not mean that these companies do not have an Improvement Proposal System or do not value input from their employees. It is just included in their CI Systems differently and does not play a significant role in describing their CI System. Furthermore, the expectation of the improvement idea proposal from the whole organization is a part of the "Culture" and "Continuous Improvement", which ranked at the first and second place at " $2-\mathrm{STRONG}$ CI System" companies. The $p$-value $<0.001$ is below $\alpha=0.05$ and states that there is a significant relationship in the responses of the different CI Maturity clusters when they describe their CI System.

When it comes to the perceived success of the existing CI approach in the companies, $100 \%$ of the "2-STRONG CI System" companies answered with a clear "Yes" (Tab. 5). $80 \%$ of "1-NO Systematic CI System" companies know that their approach is unsuccessful, and 20\% 
Tab. 6: People Engagement elements for Continuous Improvement

\begin{tabular}{|c|c|c|c|c|c|c|c|}
\hline & & 1-NO & 2-STRONG & 3-FRAGILE & Total & $\begin{array}{c}\text { Difference } \\
\text { 2-STRONG }\end{array}$ & $\begin{array}{c}\text { Difference } \\
\text { 2-STRONG }\end{array}$ \\
\hline Recognition & 2 & $(9.5 \%)$ & $7(21.9 \%)$ & $6 \quad(24 \%)$ & $15(19.2 \%)$ & +5 & +1 \\
\hline Communication & 4 & $(19 \%)$ & $4(12.5 \%)$ & $3 \quad(12 \%)$ & $11(14.1 \%)$ & 0 & +1 \\
\hline Supportive Leadership & & & $7(21.9 \%)$ & $2 \quad(8 \%)$ & $9(11.5 \%)$ & +7 & +5 \\
\hline People Involvement & 2 & $(9.5 \%)$ & $3(9.4 \%)$ & $3 \quad(12 \%)$ & $8(10.3 \%)$ & +1 & 0 \\
\hline People Development & 2 & $(9.5 \%)$ & $2 \quad(6.3 \%)$ & $3(12 \%)$ & $7 \quad(9 \%)$ & 0 & -1 \\
\hline Awareness & 4 & $(19 \%)$ & & $1 \quad(4 \%)$ & $5 \quad(6.4 \%)$ & -4 & -1 \\
\hline People Empowerment & 2 & $(9.5 \%)$ & $1 \quad(3.1 \%)$ & $2 \quad(8 \%)$ & $5 \quad(6.4 \%)$ & -1 & -1 \\
\hline Results & 1 & $(4.8 \%)$ & $1 \quad(3.1 \%)$ & $2 \quad(8 \%)$ & $4 \quad(5.1 \%)$ & 0 & -1 \\
\hline Customers & & & $2(6.3 \%)$ & $2 \quad(8 \%)$ & $4 \quad(5.1 \%)$ & +2 & 0 \\
\hline Coaching & 1 & $(4.8 \%)$ & $1 \quad(3.1 \%)$ & $(4 \%)$ & $3(3.8 \%)$ & 0 & 0 \\
\hline No Structure & 2 & $(9.5 \%)$ & & & $2(2.6 \%)$ & -2 & 0 \\
\hline Sustainment & & & $2 \quad(6.3 \%)$ & & $2(2.6 \%)$ & +2 & +2 \\
\hline Job Rotation & & $(4.8 \%)$ & & & $1 \quad(1.3 \%)$ & -1 & 0 \\
\hline $\begin{array}{l}\text { Conceptional } \\
\text { Simplification of Lean }\end{array}$ & & & $1 \quad(3.1 \%)$ & & $1 \quad(1.3 \%)$ & +1 & +1 \\
\hline Target Setting & & & $1 \quad(3.1 \%)$ & & $1 \quad(1.3 \%)$ & +1 & +1 \\
\hline Total & 21 & $(100 \%)$ & $32(100 \%)$ & $25(100 \%)$ & $78(100 \%)$ & & \\
\hline
\end{tabular}

believe it is partially successful. Interesting responses came from the "3-FRAGILE CI System" companies in every possible answer opportunity. 50\% answered that their CI approach is partially successful, whereas $20 \%$ said it is unsuccessful. The remaining $30 \%$ believe that their CI approach is successful. They justified their answers, why they believe their CI System is robust, with having "Employee Engagement", "Financial Results", "Implementation Speed", sound "Share price" development, and "Teamwork" (Tab. 9 in Annex). The $p$-value < 0.0001 indicates strong evidence against the null hypothesis and, with that, a strong relationship between CI Maturity and the perceived success of a company.

Generally looking into the detailed answers to why the respondents have rated their CI Systems success the way they did, it is evident that the top four responses from the " $2-$ STRONG CI System" companies who believe in the success of their CI System $(72 \%$ from the " $2-$ STRONG CI System" responses) are result related (Tab. 9 in Annex). The main relative differences in the answers between the "2-STRONG CI System" companies and the two other type companies are "Financial Results" ("1-NO Systematic CI System" +7, "3-FRAGILE CI System" +6 ), "Daily Improvements" ("1-NO Systematic CI System" +5, "3-FRAGILE CI System" +5 ), and "Operational Performance" ("1-NO Systematic CI System" +4, "3-FRAGILE CI System" +4). The top three responses from "1-NO Systematic CI System" companies with perceived limited to no success with their CI System are "Lack of CI Knowledge", "No Results", and "No Continuity" (46.2\% from the "1-NO Systematic CI System" responses). "3-FRAGILE CI System" companies have no significant reasons for their answers, rather than widespread reasons.

\subsection{People Engagement}

People Engagement is a comprehensive definition. How the respective companies' leaders make sure that the employees are excited about Continuous Improvement helps to understand what the companies are doing to engage their people. The top three answers were "Recognition", "Communication", "Supportive Leadership", and made up $44.9 \%$ of 
Tab. 7: People Development elements

\begin{tabular}{|c|c|c|c|c|c|c|c|}
\hline & 1-NO & 2-STRONG & $3-\mathbf{F}$ & RAGILE & Total & $\begin{array}{c}\text { Difference } \\
\text { 2-STRONG } \\
\text { to } 1-\mathrm{NO}\end{array}$ & $\begin{array}{c}\text { Difference } \\
\text { 2-STRONG } \\
\text { to 3-FRAGILE }\end{array}$ \\
\hline Method/Soft Skill Training & $1(7.1 \%)$ & $2(10.5 \%)$ & 8 & $(40 \%)$ & $11(20.8 \%)$ & +1 & -6 \\
\hline No structure & $6(42.9 \%)$ & & & & $6(11.3 \%)$ & -6 & 0 \\
\hline Internal Training Academy & $1 \quad(7.1 \%)$ & $3(15.8 \%)$ & 1 & $(5 \%)$ & $5 \quad(9.4 \%)$ & +2 & +2 \\
\hline Coaching/Mentoring & & $2(10.5 \%)$ & 3 & $(15 \%)$ & $5 \quad(9.4 \%)$ & +2 & -1 \\
\hline Kaizen & $2(14.3 \%)$ & $2(10.5 \%)$ & & & $4 \quad(7.5 \%)$ & 0 & +2 \\
\hline Immersion Training & & $3(15.8 \%)$ & 1 & $(5 \%)$ & $4 \quad(7.5 \%)$ & +3 & +2 \\
\hline Lean Expert Program & $1(7.1 \%)$ & & 1 & $(5 \%)$ & $2(3.8 \%)$ & -1 & -1 \\
\hline $\begin{array}{l}70-20-10 \text { Rule (on the } \\
\text { job-training-coaching) }\end{array}$ & & $2(10.5 \%)$ & & & $2(3.8 \%)$ & +2 & +2 \\
\hline On the Job & & $2(10.5 \%)$ & & & $2(3.8 \%)$ & +2 & +2 \\
\hline Leadership Program & & $1 \quad(5.3 \%)$ & 1 & $(5 \%)$ & $2(3.8 \%)$ & +1 & 0 \\
\hline KPI-driven learnings & & & 2 & $(10 \%)$ & $2(3.8 \%)$ & 0 & -2 \\
\hline Benchmarks & $1 \quad(7.1 \%)$ & & & & $1 \quad(1.9 \%)$ & -1 & 0 \\
\hline Fairs & $1 \quad(7.1 \%)$ & & & & $1 \quad(1.9 \%)$ & -1 & 0 \\
\hline High Potential Programs & $1 \quad(7.1 \%)$ & & & & $1 \quad(1.9 \%)$ & -1 & 0 \\
\hline Daily Study Meetings & & $1 \quad(5.3 \%)$ & & & $1 \quad(1.9 \%)$ & +1 & +1 \\
\hline $\begin{array}{l}\text { Out-of-comfort-zone } \\
\text { responsibilities }\end{array}$ & & $1 \quad(5.3 \%)$ & & & $1 \quad(1.9 \%)$ & +1 & +1 \\
\hline $\begin{array}{l}70-20-10 \text { Rule (on the } \\
\text { job-peers-trainings) }\end{array}$ & & & 1 & $(5 \%)$ & $1 \quad(1.9 \%)$ & 0 & -1 \\
\hline Empowerment & & & 1 & $(5 \%)$ & $1 \quad(1.9 \%)$ & 0 & -1 \\
\hline $\begin{array}{l}\text { Improvement } \\
\text { Proposal System }\end{array}$ & & & 1 & $(5 \%)$ & $1 \quad(1.9 \%)$ & 0 & -1 \\
\hline Total & $14(100 \%)$ & $19(100 \%)$ & 20 & $(100 \%)$ & $53(100 \%)$ & & \\
\hline
\end{tabular}

all responses (Tab. 6). The highest relative differences in the answers between the "2STRONG CI System" companies and the two other type companies are "Supportive Leadership" ("1-NO Systematic CI System" +7, "3FRAGILE CI System" +5), "Recognition" ("1NO Systematic CI System" +5, "3-FRAGILE CI System" +1), and "Awareness" ("1-NO Systematic CI System"-4, "3-FRAGILE CI System" -1). While "2-STRONG CI System" companies rated "Recognition" (21.9\%) and "Supportive Leadership" (21.9\%) as their top two activities to engage people, "1-NO Systematic CI System" companies mentioned "Communication" (19\%) and "Awareness" (19\%) as their top two contributors. The top answer from the "3-FRAGILE CI System" companies was "Recognition" (24\%), followed by "Communication" (12\%), "People Involvement" (12\%), and "People Development" (12\%).
Recognition was for both Strong and Fragile CI System companies as one of the top answers, but having a closer look at the details shows that handling recognition is different. In Fragile CI System companies, $50 \%$ of the answers related to recognition are monetary. In contrast, in Strong CI System companies, $85.7 \%$ of the answers are related to lifting people up with increasing their visibility for their efforts. The remaining $14.3 \%$ was a combination of personal recognition and a small gift. What also became apparent in this section is that the three dimensions of people excellence - people engagement, people enablement, and people empowerment are interrelated with each other as they are in every maturity type of company response.

The fact that "Awareness" was not mentioned in the "2-STRONG CI System" companies and is displayed as the third most prominent difference in the responses comes with the years 
Tab. 8: People Empowerment elements

\begin{tabular}{|c|c|c|c|c|c|c|}
\hline & $1-\mathrm{NO}$ & 2-STRONG & 3-FRAGILE & Total & $\begin{array}{c}\text { Difference } \\
\text { 2-STRONG } \\
\text { to } 1-\mathrm{NO} \\
\end{array}$ & $\begin{array}{c}\text { Difference } \\
\text { 2-STRONG } \\
\text { to } 3 \text {-FRAGILE }\end{array}$ \\
\hline Provide Authority & $2(16.7 \%)$ & $4(21.1 \%)$ & $2(13.3 \%)$ & $8(17.4 \%)$ & +2 & +2 \\
\hline Supportive Leadership & $2(16.7 \%)$ & $3(15.8 \%)$ & $3 \quad(20 \%)$ & $8(17.4 \%)$ & +1 & 0 \\
\hline Provide Resources & $2(16.7 \%)$ & $2(10.5 \%)$ & $2(13.3 \%)$ & $6 \quad(13 \%)$ & 0 & 0 \\
\hline Clear Targets & $2(16.7 \%)$ & $1 \quad(5.3 \%)$ & $3 \quad(20 \%)$ & $(13 \%)$ & -1 & -2 \\
\hline People Engagement & $1(8.3 \%)$ & $1 \quad(5.3 \%)$ & $1 \quad(6.7 \%)$ & $(6.5 \%)$ & 0 & 0 \\
\hline $\mathrm{n} / \mathrm{a}$ & $1 \quad(8.3 \%)$ & & $2(13.3 \%)$ & $(6.5 \%)$ & -1 & -2 \\
\hline Management Alignment & $2(16.7 \%)$ & & & $(4.3 \%)$ & -2 & 0 \\
\hline Coaching/Mentoring & & $2(10.5 \%)$ & & $(4.3 \%)$ & +2 & +2 \\
\hline $\begin{array}{l}\text { Sustainment } \\
\text { of Improvements }\end{array}$ & & & $2(13.3 \%)$ & $(4.3 \%)$ & 0 & -2 \\
\hline Allow Creativity & & $1 \quad(5.3 \%)$ & & $(2.2 \%)$ & +1 & +1 \\
\hline CI Framework & & $1 \quad(5.3 \%)$ & & $1 \quad(2.2 \%)$ & +1 & +1 \\
\hline Failure Culture & & $1(5.3 \%)$ & & $1 \quad(2.2 \%)$ & +1 & +1 \\
\hline $\begin{array}{l}\text { Increase Employee } \\
\text { Satisfaction }\end{array}$ & & $1 \quad(5.3 \%)$ & & $1 \quad(2.2 \%)$ & +1 & +1 \\
\hline Increase Lean Experience & & $1 \quad(5.3 \%)$ & & $1 \quad(2.2 \%)$ & +1 & +1 \\
\hline Job Rotation & & $1 \quad(5.3 \%)$ & & $1 \quad(2.2 \%)$ & +1 & +1 \\
\hline Total & $12(100 \%)$ & $19(100 \%)$ & $15(100 \%)$ & $46(100 \%)$ & & \\
\hline
\end{tabular}

the companies are already in the CI journey. Creating awareness is usually part of the change management process and happens either at the beginning of the CI journey or if a company tries to re-launch its CI program.

Regarding the relationship of the CI Maturity with the People Engagement elements, the probability value of Fischer's exact test is $p=$ 0.619 , and with that significantly higher than $\alpha=0.05$. It fails to reject the null hypothesis, which means no significant relationship exists between the different companies related to People Engagement elements.

\subsection{People Enablement}

For People Enablement, the question was about how the companies develop their people in Continuous Improvement. The top three answers from all companies were individual "Method/Soft Skill Trainings" (20.8\%), "Internal Training Academy" (9.4\%), and "Coaching/Mentoring" (9.4\%), which makes up $39.6 \%$ of all responses (Tab. 7). The most visible relative differences in the answers between the " 2
STRONG CI System" companies and the two other type companies are "No Structure" ("1NO Systematic CI System" -6), "Method/Soft Skill Training" ("1-NO Systematic CI System" +1, "3-FRAGILE CI System" -6), and "Immersion Training" ("1-NO Systematic CI System" +3, "3-FRAGILE CI System" +2). Six "1-NO Systematic CI System" companies mentioned that they have no structure to develop their employees in Continuous Improvement (42.9\% of their total responses). To gain a top-level overview, "Coaching/Mentoring" and "70-20-10 Rule (on the job-training-coaching)" with its coaching element are considered as combined. With that, the top three responses for the "2-STRONG CI System" companies would be "Coaching/Mentoring incl. 70-20-10 Rule (on the job-training-coaching)" (21.1\%), "Internal Training Academy" (15.8\%), and "Immersion Training" (15.8\%). The "3-FRAGILE CI System" companies have rated specific "Method/Soft Skill Training" (40\%), "Coaching/Mentoring" (15\%), and "KPI-driven learnings" $(10 \%)$ as their top three activities. A big emphasis is on "Method/Soft Skill Training", 
which eight out of ten of these companies use to develop their people in Continuous Improvement. In comparison, only two of the "2-STRONG CI System" companies and one of "1-NO Systematic CI System" companies are using standalone "Method/Soft Skill Training".

The $p$-value of the company CI Maturity relationship with the People Development elements is $p=0.001$ and significantly lower than $\alpha=0.05$. Therefore, it confirms the alternative hypothesis, which means a strong relationship between the CI Maturity and the People Development elements.

\subsection{People Empowerment}

The respondents' answers to how they make sure that the responsible people drive Continuous Improvement can confirm Blanchard's definition of people empowerment (Blanchard et al., 1999), with some additional directions. The top 4 answers were "Provide Authority", "Supportive Leadership", "Provide Resources", and "Clear Targets", which together represent $60.9 \%$ of all responses (Tab. 8). The highest relative differences in the answers between the "2-STRONG CI System" companies and the two other type companies are "Provide Authority" ("1-NO Systematic CI System" +2,
"3-FRAGILE CI System" +2) and "Coaching/Mentoring" ("1-NO Systematic CI System" +2, "3-FRAGILE CI System" +2). While "1NO Systematic CI System" has no significanttop approach for People Empowerment, "2STRONG CI System" companies rely on "Provide Authority" (21.1\%) and "Supportive Leadership" (15.8\%) as their top two activities for empowerment. "3-FRAGILE CI System" companies in comparison are also utilizing "Supportive Leadership" (20\%) for People Empowerment and working on "Clear Targets" (20\%) for the people.

Blanchard's definition of People Empowerment impact-providing authority and responsibility to make decisions and releasing People's Engagement, knowledge, and experienceis still valid today. In addition, the respondents also added alignment (Management and target alignment), framework, and supportive Leadership, showing interest and following up on improvement sustainment.

The null hypothesis that no relationship exists in the People Development approach in the different companies cannot be rejected as $p=0.503$ is higher than $\alpha=0.05$. This means there is no significant relationship between the CI Maturity and the People Empowerment elements.

\section{DISCUSSION}

The study demonstrates that companies with a strong CI System are more concerned about People Excellence and how they can support their people as part of the transformation. To achieve that, successful companies approach people's side of transformations in a more structured and holistic way. The fact that around $70 \%$ of the companies fail-or become fragile-to transform their business highlights the importance of working on the companies with a fragile CI System to become a strong performing CI culture, rather than having only a good set of CI tools.

In the Continuous Improvement Maturity section, it became visible that the company size is not an influencing factor, whether a Con- tinuous Improvement System is strong or not. E.g., companies with a strong CI System could be found in companies from $\$ 0-250 \mathrm{M}$ up to $>\$ 50 \mathrm{Bn}$, but also companies with no structured CI System from $\$ 0-250 \mathrm{M}$ up to $\$ 10-50 \mathrm{Bn}$.

The research findings of how leaders describe their CI System showed a clear relationship between the CI Maturity and how the leaders see their CI System. The focus of more mature companies is driven through the culture, values, and development of their people. This is in line with the current literature about the importance of culture and people's capability development (Byrne and Womack, 2013; Liker and Meier, 2006; Mann, 2015). The research findings that the companies with a strong 


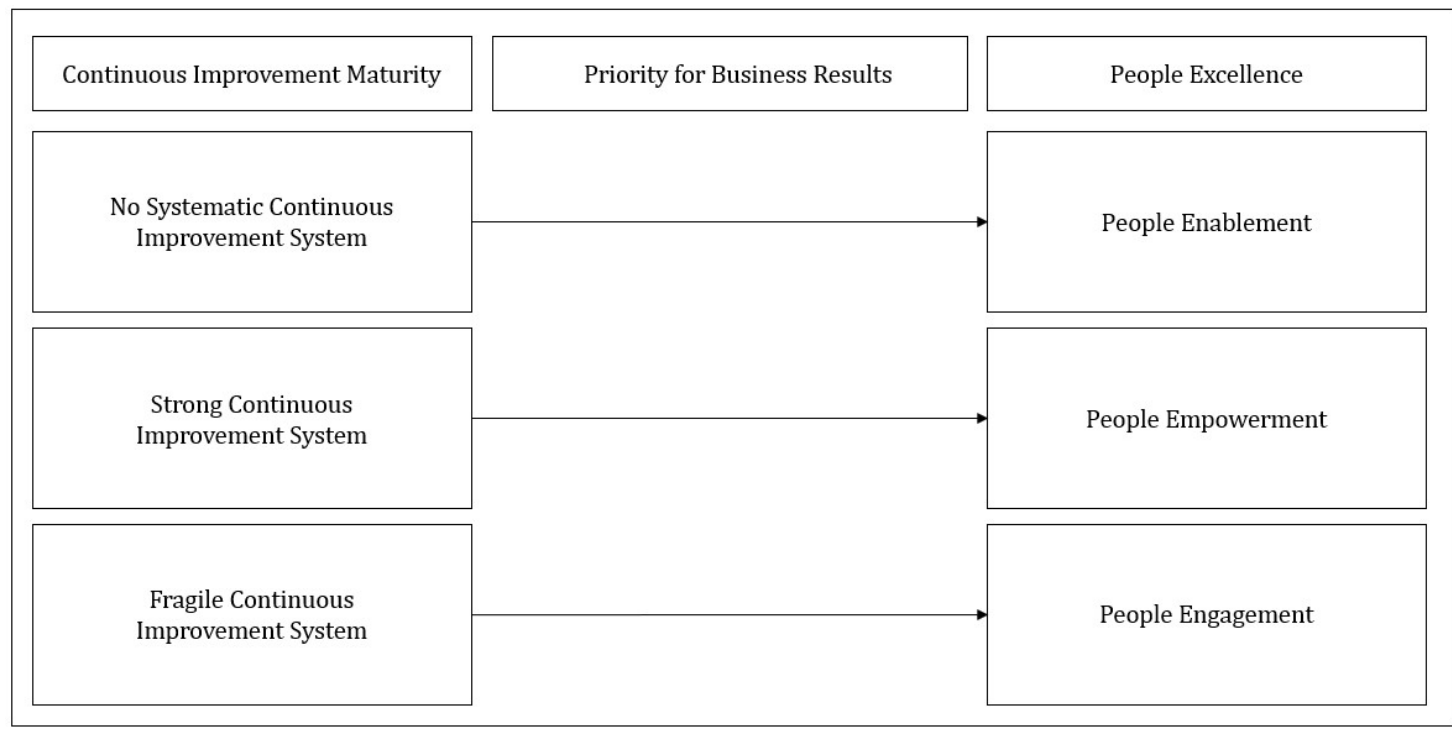

Fig. 3: CI Maturity focus on People Excellence based on research findings

CI System have a CI journey of at least 11 years behind them shows a CI System's longterm setup and that it should be considered a marathon rather than a sprint and supports existing literature (Asefeso, 2013; Liker, 2020).

The most demanding companies to transform are $30 \%$ of the companies with a fragile CI System who believe they are successful. They believe their success is because of their current CI approach, or they believe they are successful even without focusing on a CI System-because the causality or the coincidence of their success related to the CI System is not clear. This gap creates a question about the effectiveness of these companies' People Enablement methods and whether they should reconsider their people's development processes. However, since trust in the CI System is essential for its performance, these companies' priority would be to focus on People Engagement to get over the trust valley in the CI Trust Curve. The companies with no holistic CI System should focus not only on the CI System setup but also on the answer showing the most significant gap in a structured People Enablement approach. Since the People Enablement also influences People Engagement, this focus area would be a good starting point for the companies with no holistic CI System. Strong CI companies are already focusing on all three elements of People Excellence intensively. However, People Empowerment provides authority and responsibility to the people to make business decisions and release people's engagement, knowledge, and experience. Therefore, strong CI companies' priority should focus on People Empowerment while pushing the limits with Breakthrough Thinking (Fig. 3).

The research findings support the definitions of Permana related to People Excellence and build on it with the focus on Continuous Improvement (Permana et al., 2015). However, based on the research findings, the statistical relationship between CI Maturity and People Excellence is only on the People Enablement dimension. This finding also contrasts with existing literature about CI Transformations and their success factors (DeLuzio, 2020; Leuschel, 2019; Liker, 2020; Liker and Convis, 2012).

The research findings aligned with the People Empowerment definition of Blanchard and added some more details into the definition to be more specific about the People Empowerment content based on CI Transformations (Blanchard et al., 1999).

The research findings contrast with the SCurve Model from Netland and Ferdows because this research did not show a logical 
increase in performance over time (Netland and Ferdows, 2016). Nevertheless, the S-Curve Model was valuable research and served as a basis for developing the CI Trust Curve and included the transformation success rates and findings from researched sources (de la Boutetière et al., 2018; Mortson, 2020; MPI Census, 2007; Tasler, 2017).

Cultural differences limit the study results even within one company with sites in different world regions, which could not be extensively researched due to the sample size. The sample size per industry with $1-4$ interviews per industry is small and creates another limitation, which would open possibilities for further research, e.g., more in-depth analysis for a particular industry if more specific guardrails are needed. Further research of the detailed Leadership involvement in the Continuous Improvement process, including strategic and operational alignment of the companies with different CI Maturities, would bring valuable information for establishing a strong performing CI organization. A financial analysis of the CI Trust Curve based on companies in the given Maturity phases would help confirm the Model based on hard facts. Further research for a practical and easy-to-use CI Maturity Assessment would help practitioners identify the current CI Maturity of their organization.

\section{CONCLUSIONS}

The research's general purpose was to identify how companies with different Continuous Improvement (CI) Maturities approach People Excellence for significant business results. The goal was also to explore the different views on Continuous Improvement Systems and their impact on the organization. The interview process displayed that leaders from different CI Maturity companies mean different things even when they talk about the same element. It starts with their description of the CI Systems and also includes single elements of the People Excellence. There are different gaps in the People Excellence areas based on the CI Maturity of the organization. Focusing on them individually will help leaders inspire their people to achieve significant business results in the CI journey.

Based on these conclusions, practitioners should consider evaluating their organization's CI Maturity first before designing a Lean RollOut Plan or setting up their Change Management program.
The study has provided insights to understand how the companies with the different Continuous Improvement Maturities understand Continuous Improvement as a system, the approaches for People Engagement, People Enablement, and People Empowerment to utilize Continuous Improvement with People Excellence to achieve sustainable results. The S-Curve Model has been reviewed and adapted based on the existing literature and the interview responses. The defined CI Maturity phases helped find suitable action areas in People Excellence and described how trust in a CI System correlates with business performance. This paper has provided arguments, interviewing two famous Lean Authors in the field of Lean Leadership and 28 top leaders, that the focus on people pays off not only in creating a unique Continuous Improvement culture but also in achieving outstanding financial and operational results for their company.

\section{REFERENCES}

Asefeso, A. 2013. Lean Implementation: Why Lean Fails and How to Prevent Failure. Swindon, UK: AA Global Sourcing.

Begecarslan, M. 2017. Why Leadership Matters in Lean Transformations. IfM Impulse, 22-31.
Blanchard, K. H., Carlos, J. P. and Randolph, W. A. 1999. The 3 Keys to Empowerment: Release the Power Within People for Astonishing Results. 1st ed. San Fransisco: Berrett-Koehler Publishers. 
Byrne, A. and Womack, J. P. 2013. The Lean Turnaround: How Business Leaders Use Lean Principles to Create Value and Transform Their Company. New York: McGraw-Hill.

De la Boutetière, H., Montagner, A. and REICH, A. 2018. Unlocking Success in Digital Transformations. McKinsey \& Co.

DeLuzio, M. C. 2020. Flatlined: Why Lean Transformations Fail and What to Do About It. New York, NY: Routledge.

DePoy, E. and Gitlin, L. N. 2011. Introduction to Research: Understanding and Applying Multiple Strategies. 4th ed. St. Louis, Mo: Elsevier/Mosby.

Donovan, R. M. 2015. Lean Manufacturing: Performance Evaluation Audit. R. Michael Donovan \& Co.

Edgeman, R. 2019. Complex Management Systems and the Shingo Model: Foundations of Operational Excellence and Supporting Tools. New York, NY: Routledge.

Hiatt, J. M. and Creasey, T. J. 2012. Change Management: the People Side of Change; an Introduction to Change Management from the Editors of the Change Management Learning Center. 2nd ed. Loveland, CO: Prosci Learning Center Publications.

KING, N. and Horrocks, C. 2010. Interviews in Qualitative Research. London: Sage Publications.

Kremer, R. and TApping, D. 2007. The Lean Assessment for Job Shops and Small Manufacturers. Chelsea, MI: MCS Media.

Leuschel, S. 2019. Why Lean Transformation Fails: Common Challenges to Adopting New Leadership and Management Systems. Align Kaizen.

LikeR, J. K. 2020. The Toyota Way: 14 Management Principles from the World's Greatest Manufacturer. 2nd ed. New York: McGraw-Hill Education.

Liker, J. K. and Convis, G. L. 2012. The Toyota Way to Lean Leadership: Achieving and Sustaining Excellence Through Leadership Development. New York: McGraw-Hill.

Liker, J. K. and Meier, D. 2006. The Toyota Way Fieldbook: A Practical Guide for Implementing Toyota's 4Ps. New York: McGraw-Hill.

Magnusson, E. and MareceK, J. 2015. Doing Interview-Based Qualitative Research: A Learner's Guide. Cambridge: Cambridge University Press.

Maier, S. 2019. 'People Enablement' is the Human-Resources Trend You Can't Ignore. Entrepreneur [online]. Available at: https://www. entrepreneur.com/article/337228.

Mann, D. 2015. Creating a Lean Culture: Tools to Sustain Lean Conversions. 3rd ed. CRC Press.

MAYRING, P., 2010. Qualitative Inhaltsanalyse: Grundlagen und Techniken, 11th ed. Beltz Pädagogik. Weinheim: Beltz.
McPhie, N. A. G. 2008. The Power of Federal Employee Engagement. U.S. Merit Systems Protection Board Report.

Mertens, D. M. 2005. Research and Evaluation in Education and Psychology: Integrating Diversity with Quantitative, Qualitative, and Mixed Methods. 2nd ed. Thousand Oaks, CA: Sage Publications.

Mortson, M. 2020. 10 Signs You Should Reboot Your Lean Program! [online]. Available at: https://supplychaingamechanger.com/ global-process-excellence-part-7-10-signsreboot-lean-program/.

[Accessed 2020, November 1].

MPI Census. 2007. North America Manufacturing Benchmarks $\&$ Outlook for 200\%. The MPI Group.

Müller, M. 2018. The 5 Types of Business Transformation [online]. Available at: https://www . insideboard.com/blog/ the-5-types-of-business-transformations/. [Accessed 2020, December 14].

Nesensohn, C., Bryde, D., Ochieng, E., Fearon, D. and Hackett, V. 2014. Assessing Lean Construction Maturity. In Proceedings IGLC-22, People, Culture and Change, 1157-1168.

Netland, T. H. and Ferdows, K. 2016. The S-Curve Effect of Lean Implementation. Production and Operations Management, 25 (6), 1106-1120. DOI: $10.1111 /$ poms.12539.

Nightingale, D. J. and Mize, J. H. 2002. Development of a Lean Enterprise Transformation Maturity Model. Information Knowledge Systems Management, 3 (1), 15-30.

Panneman, T. 2017. Lean Transformations: When and How to Use Lean Tools and Climb the Four Steps of Lean Maturity. CreateSpace Independent Publishing Platform.

Permana, I., Tuakraatmadja, J. H., Larso, D. and Wicaksono, A. 2015. Exploring Potential Drivers of Employee Engagement, Enablement, and Empowerment: A Quest Toward Developing a Framework for Building Sustainable Employee Excellence for Manufacturing Environment in Indonesia. Mediterranean Journal of Social Sciences, 6 (2), 577-587. DOI: $10.5901 / \mathrm{mjss} .2015 . v 6 n 2 \mathrm{~s} 1 \mathrm{p} 577$.

Plenert, G. J. 2018. Discover Excellence: An Overview of the Shingo Model and Its Guiding Principles. The Shingo Model Series. Boca Raton, FL: CRC Press.

Purkey, W. W. and Siegel, B. L. 2003. Becoming an Invitational Leader: A New Approach to Professional and Personal Success. Atlanta, GA: Humanix Books.

Saunders, M. N. K., Lewis, P. and Thornhill, A. 2019. Research Methods for Business Students. 8th ed. New York: Pearson. 
Shinohara, I. 1988. NPS, New Production System: JIT Crossing Industry Boundaries. Cambridge, MA: Productivity Press.

Shishkov, B. (ed.). 2016. Business Modeling and Software Design. Selected papers from 5th International Symposium, BMSD 2015, Milan, Italy. DOI: 10.1007/978-3-319-40512-4.
TASLER, N. 2017. Stop Using the Excuse "Organizational Change Is Hard". Harvard Business Review.

Womack, J. P., Jones, D. T. and Roos, D. 1990 The Machine that Changed the World: Based on the Massachusetts Institute of Technology 5-Million Dollar 5-Year Study on the Future of the Automobile. New York: Harper Perennial.

\section{ANNEX}

Tab. 9: Reasons for success classification

\begin{tabular}{|c|c|c|c|c|c|}
\hline CI Successful & Reasons for classification & $1-\mathrm{NO}$ & 2-STRONG & 3-FRAGILE & Total \\
\hline Not successful & Lack of CI Knowledge & $3(23.1 \%)$ & & & $(6 \%)$ \\
\hline Not successful & No Results & $2(15.4 \%)$ & & & $(4 \%)$ \\
\hline Not successful & No Continuity & $1(7.7 \%)$ & & $1(8.3 \%)$ & $(4 \%)$ \\
\hline Not successful & Lack of Management Focus & $1 \quad(7.7 \%)$ & & & $(2 \%)$ \\
\hline Not successful & No Drive to Change & $1 \quad(7.7 \%)$ & & & $(2 \%)$ \\
\hline Not successful & No System & $1 \quad(7.7 \%)$ & & & $(2 \%)$ \\
\hline Not successful & Only Tool Level & $1 \quad(7.7 \%)$ & & & $(2 \%)$ \\
\hline Not successful & System change - Too early in journey & & & $1 \quad(8.3 \%)$ & $(2 \%)$ \\
\hline Partially & Huge Effort & $1 \quad(7.7 \%)$ & & $1 \quad(8.3 \%)$ & $(4 \%)$ \\
\hline Partially & Benchmark & $1(7.7 \%)$ & & & $(2 \%)$ \\
\hline Partially & Transparency & $1(7.7 \%)$ & & & $(2 \%)$ \\
\hline Partially & Limited Financial Results & & & $1(8.3 \%)$ & $(2 \%)$ \\
\hline Partially & Management attention & & & $1(8.3 \%)$ & $(2 \%)$ \\
\hline Partially & Only Tool Level & & & $1(8.3 \%)$ & $(2 \%)$ \\
\hline Partially & System change - Too early in journey & & & $1(8.3 \%)$ & $(2 \%)$ \\
\hline Partially & System satisfaction & & & $1(8.3 \%)$ & $(2 \%)$ \\
\hline Successful & Financial Results & & $7 \quad(28 \%)$ & $1(8.3 \%)$ & $(16 \%)$ \\
\hline Successful & Daily Improvements & & $5 \quad(20 \%)$ & & $(10 \%)$ \\
\hline Successful & Operational Performance & & $4 \quad(16 \%)$ & & $(8 \%)$ \\
\hline Successful & Share price & & $2 \quad(8 \%)$ & $1(8.3 \%)$ & $(6 \%)$ \\
\hline Successful & Teamwork & & $(4 \%)$ & $1(8.3 \%)$ & $(4 \%)$ \\
\hline Successful & Benchmark & & $(4 \%)$ & & $(2 \%)$ \\
\hline Successful & Customers & & $(4 \%)$ & & $(2 \%)$ \\
\hline Successful & Employee Retention & & $(4 \%)$ & & $(2 \%)$ \\
\hline Successful & Flow & & $(4 \%)$ & & $(2 \%)$ \\
\hline Successful & Leadership involvement & & $1 \quad(4 \%)$ & & $(2 \%)$ \\
\hline Successful & Strategy & & $(4 \%)$ & & $(2 \%)$ \\
\hline Successful & Employee Engagement & & & $1 \quad(8.3 \%)$ & $(2 \%)$ \\
\hline Successful & Implementation speed & & & $1 \quad(8.3 \%)$ & $(2 \%)$ \\
\hline Total & & $13(100 \%)$ & $25(100 \%)$ & $13(100 \%)$ & $51(100 \%)$ \\
\hline
\end{tabular}

\section{AUTHOR'S ADDRESS}

Metin Begecarslan, Department of Management, Faculty of Business and Economics, Mendel University in Brno, Zemědělská 1, 61300 Brno, Czech Republic, e-mail: metin.begecarslan@web.de 